\title{
Senate Health Bill Lacks 50 Votes Needed to Proceed
}

Yesterday (7/17), two additional Senators - Sen. Roberts (R-KS) and Sen. Lee (R-NE) joined Senators Paul (R-KY) and Collins (R-ME) in announcing their intention to vote "no" on the motion to proceed on considering the Senate ACA repeal and replace legislation - effectively blocking Senate consideration of the current Senate Republican health care bill. Senators Paul, Lee and Roberts opposed the bill for not going far enough, while Senator Collins expressed her concern the bill goes too far.

With the 4 publicly announced NO votes - Senator Majority Leader Mitch McConnell does not have the 50 votes needed to begin debate on the bill, let alone assure final passage.

Speculation now turns to what happens next. President Trump has tweeted his preference to let Obamacare fail as a way to force Democrats to negotiate new legislation. Senator McConnell has suggested a series of symbolic votes on full repeal with multi-year delay to work on a replacement plan or voting on the House passed bill. However, three moderate senators, Capito (R-WV), Collins (R-ME) and Murkowski (R-AK), announced today they will not support procedural votes on an immediate ACA repeal bill. Alternatively, Congress may abandon the health reform effort for the time being and pivot to other legislative priorities (tax reform and infrastructure). The failure of McConnell to lead the Senate effort may clear the way for a bipartisan effort to address the shortfalls of the ACA.

Please keep in mind the House repeal and replace effort "died" before the House ultimately passed its repeal legislation, so while the Senate effort looks to be "permanently stalled" it is probably premature to call it "dead."

Nuala S. Moore

American Thoracic Society

Washington, DC USA 